\title{
A!
}

This is an electronic reprint of the original article.

This reprint may differ from the original in pagination and typographic detail.

Alaca, Ilgim Veryeri; Aktas, Bilge Merve

\section{Exploring material culture of carpets in Turkey via an art project}

Published in:

ART, DESIGN AND COMMUNICATION IN HIGHER EDUCATION

DOI:

10.1386/adch.18.1.17_1

Published: 01/04/2019

Document Version

Peer reviewed version

Published under the following license:

Unspecified

Please cite the original version:

Alaca, I. V., \& Aktas, B. M. (2019). Exploring material culture of carpets in Turkey via an art project. ART, DESIGN AND COMMUNICATION IN HIGHER EDUCATION, 18(1), 17-34.

https://doi.org/10.1386/adch.18.1.17_1

This material is protected by copyright and other intellectual property rights, and duplication or sale of all or part of any of the repository collections is not permitted, except that material may be duplicated by you for your research use or educational purposes in electronic or print form. You must obtain permission for any other use. Electronic or print copies may not be offered, whether for sale or otherwise to anyone who is not an authorised user. 


\section{Exploring material culture of carpets in Turkey via an art project}

\section{ABSTRACT}

\section{KEYWORDS}

This article reports on an art project carried out by undergraduates in a core course entitled 'Art and Innovation' offered at Koc University in Istanbul, based on traditional handmade Turkish carpets. The project enables 23 undergraduates from various disciplines to become acquainted with material culture and art as they reflect on the carpets' declining presence in contemporary culture. The goals of the project are first to acquaint the students with the art history and symbolism of carpets from Turkey, then to invite students to investigate contemporary artworks created in relation to carpets and finally to move into sketching and discussions later to have the students conceptualize an artwork that reflects the changing status of handmade carpets and the weaving tradition as an indicator of transformations in society.

\section{INTRODUCTION}

This article presents an art-course project that takes students outside a typical classroom setting to examine the significance of handmade carpets traditionally found in Turkish homes. As a significant example of material culture in Turkish society, what impact has the carpet had as a hybrid aesthetic object
Carpet

craft

art

material culture

Turkey

higher education cultural heritage materiality 
in the home? What is the relationship between material culture and the self?

How can art help us unravel these issues? Through art and research, students deliberate on the metamorphosis of carpets in concert with the blurring of boundaries between self and society, space and material culture, permanence and transformation. This endeavour inspires students to put their intuition, analytic thinking and creativity into action, looking both within and outside of themselves and recognizing that they are not only spectators but also critical actors in society and active agents in spaces that they inhabit. Students use this art project on time-honoured carpets as a vehicle to share their perceptions on the changing role of material culture and exemplifying the transformation of culture in Turkey.

Offered by the Media and Visual Arts department, the project is part of a core course entitled Art and Innovation that fuses analytical thinking with art practice while synthesizing eastern and western art history. This course focused on honing aesthetic and interpretative understanding is taught by the first author, who herself is an artist, at Koç University, a liberal arts college in Istanbul. Respecting the university's emphasis on building interdisciplinary connections, this course welcomes all undergraduates and aims to familiarize them with art by making connections to real life in general. This specific project integrates knowledge and creativity while encouraging students to view material culture through the lens of art and aims to provoke students to question, research and portray their material culture in a creative way to fulfil this overarching purpose. Hence, the project attempts to move beyond being merely an introspective activity and aims at creating an awareness of art's role in developing critical views on societal transformations that students can apply to the outside world after the course is complete.

Since this course includes students from different backgrounds, it is structured to facilitate an understanding of art first and material culture second. This provides the students majoring in a field other than art, the tools to engage in an artistic endeavour and express themselves using artistic language on a given issue. Making use of what the changing role of the carpet means to society is critical to bringing personal insights to the surface as opposed to making clinical observations. Eisner (2008: 7) states that utilizing art in research is ingenious, comparing it to a 'deep conversation' as a means of surfacing a multitude of perspectives rather than seeking a single answer to a problem. Unlike scientific inquiry, art permits students to take a personal stand on issues and react in subjective ways that makes sense to them and potentially to others. Thus, this project enables diverse points of view to take form in creative ways while facilitating an artistic dialogue enriched through multiple critical lenses such as sustainability of crafts, women's issues and societal change.

This project advances education that intertwines material culture with art and furthers the premise that one inhabits, passes on and shares'cultural ecology', as put forth by Kokko and Dillon (2016: 22). In this study, cultural ecology views the constantly mutating interactions of people with each other and with material culture as they negotiate their past and present according to their preferences. Prown (2009: 220) describes material culture as 'the study through artefacts of the beliefs - values, ideas, attitudes, and assumptions - of a particular community or society at a given time'. In this case, the material culture of carpets is viewed as both a signifier of cultural heritage and one of societal change as carpet's meaning, designs, makers and users are in constant flux, which gives them multiple layers that unfetters students' creative and 
1. critical thinking. By acknowledging the changing role of carpets in Turkey, the

2.

3.

4.

5.

6.

7.

8.

9.

10.

11.

12.

13.

14.

15.

16.

17.

18. students pay tribute to Lowenthal's idea that cultural heritage requires continuous rereading to maintain its presence in society (2000).

When students work on projects that are relatable, they not only deepen their understanding of the material culture that they identify with but also connect to their culture with increased confidence (Aronson and Laughter 2016). This study aimed to open up new discussions in relation to material culture by using art in an all-inclusive approach in contrast to the purely visual approach,

The multi-sensory orientation of material culture studies is congruent with contemporary trends in arts and culture and will permit art educators to facilitate the aesthetic imagination necessary to engage and to participate with contemporary arts and cultural experiences as well as appreciating and understanding the history of arts and culture in a much more holistic way.

(Bolin and Blandy 2003: 255)

Carpets are cultural objects with sentimental significance and a history that goes back for generations, identifying potentially the owner's and the maker's background, and the community's. The carpets play the dual role of being domestic artefacts and family heirlooms. Türe and Ger (2016: 1-2) study heirlooms by considering diverse consumer perspectives in areas such as 'curatorial consumption, guardianship, object attachment, and inalienability' and note that 'studying heirloom transformation may reveal new ways through which consumers interpret modernity and tradition, and negotiate the past, the present, and the future', a theory that can also be applied to labour conventionally done by women (Figure 2) and their changing status in society. Although carpet weaving was typically done by women, since the mid-1800s, machine production has replaced handmade production, which diminished the role of craftswomen and modified carpet designs (Quataert 1986). With the demand for handmade carpets declining, women gradually moved away from weaving carpets to more contemporary occupations.

Miller states that the transformation of material culture is essential in transforming humanity,

We cannot know who we are, or become what we are, except by looking in a material mirror, which is the historical world created by those who lived before us. This world confronts us as material culture and continues to evolve through us.

For most students, carpets are a common denominator and embody material culture, cultural heritage and art, thereby offering a valuable signifier of shifting societal standards. Jacobs and Gabriel (2013: 214) note that in our houses, we may not always pay attention to objects, but they can still impact us indirectly. Hence, this art project facilitates an awareness of cultural transformations and the influence of material culture on everyday thinking by studying and reflecting on carpets and their material and metaphoric qualities.

Exploring changing domestic needs and material culture, the project draws attention to an ancient craft to examine the transformation of a selected object over time, in this case the carpets in most students' homes. The course 
IIgım Veryeri Alaca | Bilge Merve Aktaș

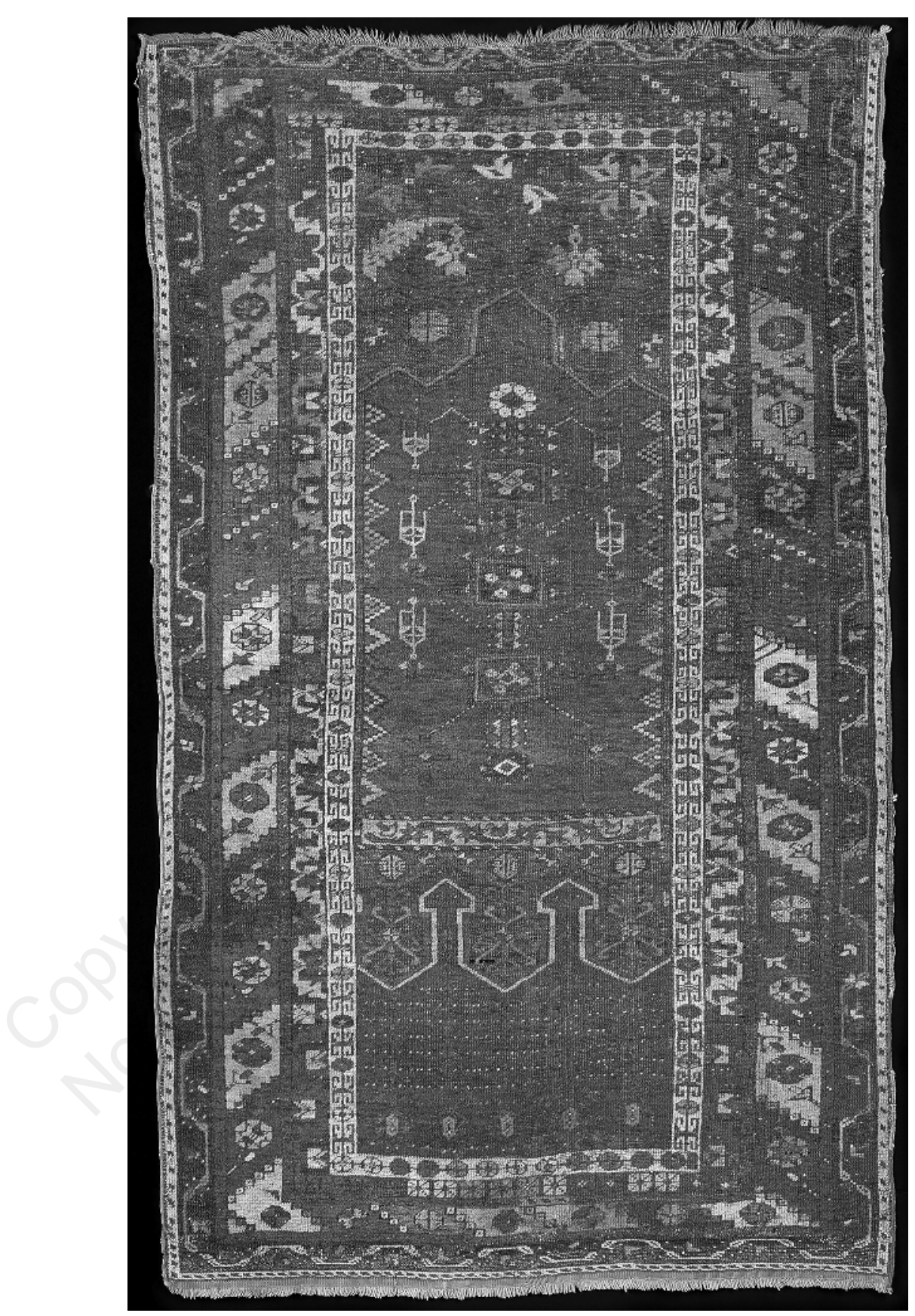

1.

2.

3.

4.

5.

6.

7.

8.

9.

10.

11.

12.

13.

14.

15.

16.

17.

18.

19.

20.

21.

22.

23.

24.

25.

26.

27.

28.

29.

30.

31.

32.

33.

34.

35.

36.

37.

38.

39.

40.

41.

42.

43.

44.

45.

46.

Figure 1: Konya Ladik Carpet, Ottoman period nineteenth century. Courtesy of Vehbi Koç Foundation Sadberk Hanım Museum, İstanbul. 


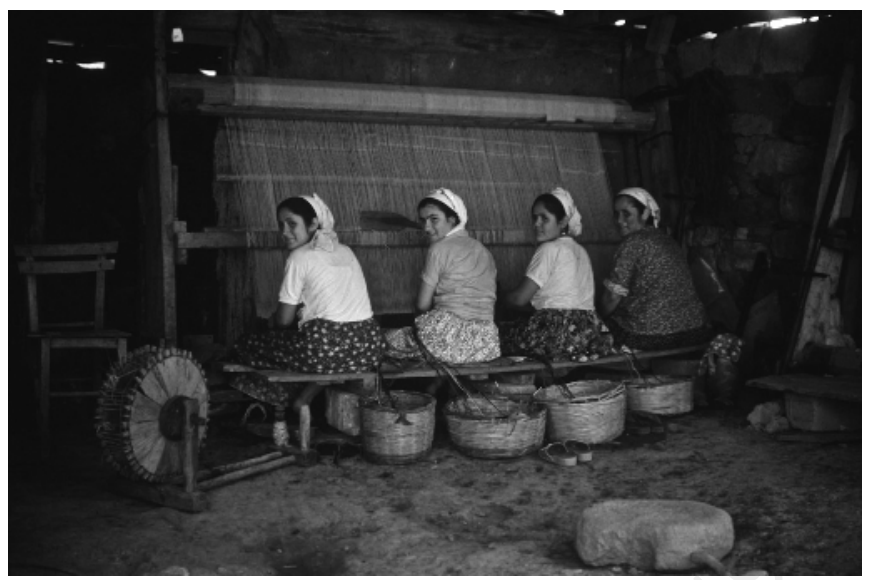

Figure 2: Four women at the loom weaving a carpet (1987). Josephine Powell Slide Collection, 18 January 2017, Suna Kuraç Library, Koç University. http://digitalcollections.library.ku.edu.tr/cdm/landingpage/collection/JPC.

conducted surveys to examine the students' knowledge on carpets and the memories related to them. After studying transformations in carpets and carpet making from an art history and contemporary art perspective, students were asked to conceptualize an artwork inspired by the discussions that they had during the course.

\section{HANDMADE CARPETS IN ART AND SOCIETY}

Utilizing carpets and their historical evolution as a starting point, this project provides a forum to discuss changes in Turkish society through art. Besides historical knowledge on the carpets and carpet making, students are shown artworks that depict carpets in different eras and chronicle the transformation of carpets. Historically portrayed as magical in fairy tales, handmade carpets are one of the world's oldest art forms, and to this day their allure extends beyond mundane domestic or utilitarian uses (Figure 1). Although the production of handmade carpets has declined, the value of these carpets and the carpet culture remains high, generating both admiration and critical thinking. Between the fifteenth and the eighteenth centuries, carpets from Turkey were immortalized in paintings by such famous European artists as Holbein, Lotto, Memling, Van Eyck, Bellini, Ghirlandaio and Crivelli, and to this day these 'painter carpets' are known by the name of the artist who painted them (Atil 1980; Denny 2003).

Carpets once celebrated in famous European and American paintings are now utilized in contemporary art in edifying ways. Examples include various artistic approaches that use carpets to broach discussions on politics (see Afghan war carpets, Spooner 2011), on hybridizing ethnic backgrounds (see exhibition Without Boundary, Daftari et al. 2006), on identity formation (see Nevin Aladağ's Paravent/Social Fabric work, Masters 2015) or on how to personalize carpets via digital applications (see Kolatan and MacDonald in 1st Istanbul Design Biennale, 2012, Kapucu and Shafrir 2012). Carpets are also used in other art forms, including world literature (see 'The wish', by Roald Dahl) and children's books in Turkey (see Ninemin Kilimi ['Grandmother's Carpet'] by Aysel Gürmen 2008). 
Aside from being used for social commentary and literary works, carpets have also been studied in art class to examine visual culture. In a cross-cultural study by Professor Stokrocki (2001), she explored how a select group of children around the age of ten of Turkish, Navajo and Japanese backgrounds described a Turkish carpet and its motifs, uncovering different surmises in the process. The children's responses indicated that their perception of each symbolic element on the carpet was influenced by their culture, spawning a variety of conjectures. At the end of the study, all the participants claimed that they would look more closely at the carpets that they had at home, proving that the project had made them more aware of carpets as visual elements of their home.

Carpet making was originally geared towards personal use, leading to a home-based domestic industry, which was then turned into workshops where family members worked collaboratively (Figure 2). Despite the enduring history of carpets in Turkey, their presence in the contemporary home is fading as carpet making is not an extension of daily routines and its craftsmanship is time-consuming (Figures 3-4). Hart (2011) conducted a two-year-long ethnographic study in a village that depends on income from carpet making, which concluded that, although once an heirloom and substantial part of dowries, carpets have become commercial objects.

Handmade carpets, which are costly and at times considered old-fashioned, have now been to some degree done away with or substituted with minimally coloured machine-made carpets. High-quality handmade carpets are a tourist attraction or a decorative object for the privileged. On occasion, the production process is demonstrated by women, mostly villagers, in touristic shops with the aim of promoting carpets as desirable and exotic items (Hart 2011). Although handmade carpets have undergone a social shift from domestic to commercial, they or their substitutes are still significant components of domestic space that do make impact with their form, shape, position and design.

Knowledge acquired from different eras in relation to carpets foregrounded the historic evolution of material culture and the inherent shifting values. By positioning the social change through material culture and reflecting on how this history affected everyday life, students were given a starting point and motivated to study their personal and family histories in relation to carpets, evoking memories and interactions around carpets. Since their assignment was to conceptualize an artwork, the historical information on carpet making provided a wealth of material, offering intricate details to either use faithfully or alter, and their personal history provided a source of sentiment and connection that added a depth of feeling to their art.

\section{STUDYING MATERIAL CULTURE OF CARPETS VIA ARTS}

By using carpets as the focal point, this study employs art as a method to understand one's own material culture while developing new questions and meaning-making. Students process information gleaned from discussions, explorations and observations to conceptualize their opinions on the carpet's evolution. Art can be an experiential facilitator for the students to adopt an open-ended, personal position based on their thoughts, investigations and artistic experimentation, enriching their contemplation and communication capacity in a personally relevant way (van den Akker 2014). As McNiff (2008) argues, creativity can be an instrument to allow students to examine situations both as an insider and as an outsider at once. Having the double agency of creative and critical thinking affords students a multi-angled approach. As

1. 2. 3. 4. 5. 6. 7. 8. 9. 10. 11. 12. 13. 14. 15. 16. 17. 18. 19. 20. 21. 22. 23. 24. 25. 26. 27. 28. 
1. Dunnigan (2013: 98) suggests, 'critical making' may require being deeply

2. involved in an issue before potentially resulting in novel findings.

The project bases its premise on the assumption that students are familiar with carpets since many have grown up in homes decorated with all manner of handmade textiles and carpets. On the one hand, this familiarity means that they have the fundamental knowledge needed to perceive changes in everyday interactions with the material world through an artistic lens. On the other, this familiarity could mean that they take the material culture around them for granted and have ceased to notice carpets critically. Giannachi et al. (2012: 2) note'the experience of presence has often been linked to practices of encounter and to perceptions of difference and relation with something or somebody, as well as the uncanny encounter with one's own sense of self'. Thus, Maarit Mäkelä and Teija Löytönen (2017: 254) exemplify how being sensitive to one's environment and its material properties can be linked to learning in higher education when intertwined with arts, stating, 'materiality teaches in its own way and the learning setting plays an important role'. Accordingly, two questionnaires were conducted to motivate students to think about their interactions with the carpets. We made use of students' everyday experiences throughout the project in relating to the carpets' conceptual, sensual, two- and three-dimensional presence while introducing art as a form of inquiry. Students were impelled to think about and sketch the stereotypical and unusual placement of carpets in real and imaginary spaces, in addition to carpets' relation to other objects to encourage spatial and creative thinking. By comparing the typical position of a carpet in a house with the artistic placement of carpets in an artwork started students conceptualize this form in real and artistic realm.

Spatial thinking and reasoning are essential to understand real-life concepts and the abstract ones found in art and science. Grossner and Janelle (2014) suggest that people are engaged with spatiality physically and mentally. For instance, flatness is a distinguishing feature of carpets similar to the flat art concept that has spread to wall, floor and ceiling paintings. In this respect, carpets introduce an inquiry: first, in terms of visual thinking and second, in terms of space. Tilburg (2011) talks about flatness by focusing on carpets_and by examining artworks by various artists, such as Louise Bourgeois, focusing on the idea of a plural space. Plural space, initially used by Julia Kristeva to define the art of Bourgeois is a concept that dwells on blurring the boundaries of self and space through many layers of perception, from conceptual to sensory. Putting her own spin on this concept, Tilburg uses the weaving process to illustrate the complexity of this flatness and the relation between outside and the inside as the same thread now surfaces and then goes under, thereby showing the ways, in which outside becomes inside and inside becomes outside, and different concepts and experiences of space fold into each other' (Tilburg 2011: 139). Tilburg's idea was also discussed in class based on the embroidered masks of Bourgeois, essentially tapestry-covered faces. In these works, the surface is covered in needlepoint designs that appear decorative at a distance, but when examined up close evokes a disconcerting feeling due to individual stitches being visible, particularly unnerving around the eyes, cheeks and lips, giving the flesh a rather unusual texture.

By incorporating more contemporary artworks, this project attempts to go beyond the traditional ideas on carpets so that the students not only learn about history but also contemplate the layered issues that have led to this art diminishing as labour-intensive jobs such as carpet weaving are aban52. doned and younger generations seek contemporary occupations. Students 


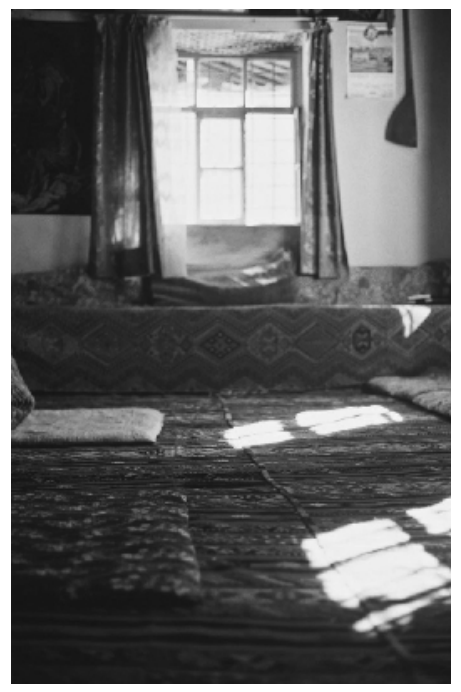

Figure 3: The Ăga's House (1978). Malatya (Gülpinar Village), Turkey, Josephine Powell Slide Collection, 18 January 2017, Suna Kıraç Library, Koç University. http:// digitalcollections.library.ku.edu.tr/ cdm/landingpage/collection/JPC.

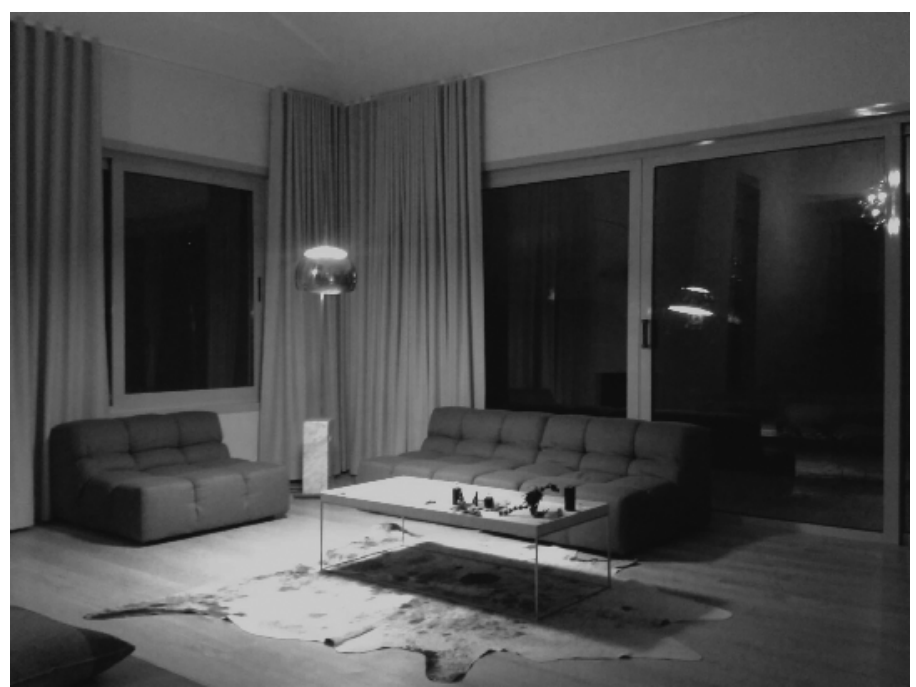

Figure 4: The living room (2017). İstanbul, Turkey. Copyright Ilgim Veryeri Alaca.
1.

2.

3.

4.

5.

6.

7.

8.

9.

10.

11.

12.

13.

14.

15.

16.

17.

18.

19.

20.

21.

22.

23.

24.

25.

26.

27.

28.

29.

30.

31.

32.

33.

34.

35.

36.

37.

38.

39.

40.

41.

42.

43.

44.

45.

46.

47.

48.

49.

50.

51.

52. 
1. was divided into two stages. In stage one, students filled out a questionnaire 2. as a means of jotting down their pre-instruction thoughts and memories 3. about carpets, which provided an explicit catalogue of their implicit knowledge. Initial questions were geared towards gathering their insights pertaining to carpets by asking them to complete the sentence 'A carpet is [...]'. Some meaningful answers to this question summed up the emotional, cultural and spatial aspects of the carpet's impact:

- a design (MK)

- represents your cultural background and your tradition (ZŞ)

- memory (İBÖ)

- an object that makes a house home (LHÇ)

Another question was aimed at documenting the students' knowledge in terms of carpet-related terminology. Some of the keywords that they identified included ideas about the production process (i.e. weaving, knots), materials (i.e. yarn made of sheep's wool or silk), motifs and symbolism (i.e. motifs representing life, death, fertility and power). They also distinguished styles and traditions in carpet production by different regions, and the significance of carpets in terms of being passed down through generations. Most of the students revealed that there was at least one handmade carpet in their home, one admitting that she keeps the carpet in memory of her grandmother. When they were asked to tell their carpet's story, only a few students were able to provide information:

[...] It is a huge carpet decorated with a combination of both Turkish and Romanian traditional cultural figures. My grandmother who was a Romanian immigrant brought it to Turkey and she used to tell me that they used to make these carpets in Romania to reflect their Turkish cultural heritage.

Nineteen of the students expressed that they liked handmade carpets, one student expressing an interest in the delicate, detailed and repetitive patterns that varied slightly from each other (ACÖ). Whether they expressed appreciation for the carpets or not, the students agreed that there is a bond between carpets, houses and emotions. Students also stated that carpets might go beyond the domestic domain and constitute ties between societies. After answering the questionnaire, students were asked to write out their childhood memories about carpets. More than half of the students could summon up a personal story about a carpet, sharing spatial, tactile information and capturing sensory-rich descriptions referring to the way carpets were used, valued and cherished:

[...] I remember a carpet from my grandparents' house that my grandmother wouldn't let me or anyone step on. I guess it was called a Bunyan.

[...] I have the memory of a carpet that belongs to my grandmother which was very large and they would have to move all the furniture to wrap it every summer. 
After submitting their answers, students were presented with historical facts about carpets, introducing them to motifs, materials and techniques used in carpet production, and artworks that utilize carpets. Then to create a carpet design on paper, they used rubber stamps (Figure 5) with carpet motifs in various combinations to compose different themes. This exercise aimed at presenting the storytelling aspect of handmade carpets, encouraging students to use motifs to convey messages.

In stage two, students were presented with two sets of questions and a follow-up exercise before they started the production phase of their work. These questions aimed at facilitating constructive critiques on carpet making and the carpets' place within contemporary society. The first set of questions was meant to help students define the role of carpets in a larger context and explore the role of carpets in everyday life. These questions initiated dialogue pinpointing certain notions that people hold on carpets, the influence that the carpets have had at home and how they are disappearing from modern homes. We opened with a discussion on the dwindling presence of carpets once an essential part of material culture in Turkish homes - and the declining carpet culture, which has resulted in a decrease in know-how, the continuity of handmade carpet manufacturing and women's status. Studying the production processes allowed students to observe social conditions related to carpet making and form their own opinions on social issues such as labour and gender. The follow-up exercise encouraged students to play around with carpet concepts through a sketching activity as a warm-up study.

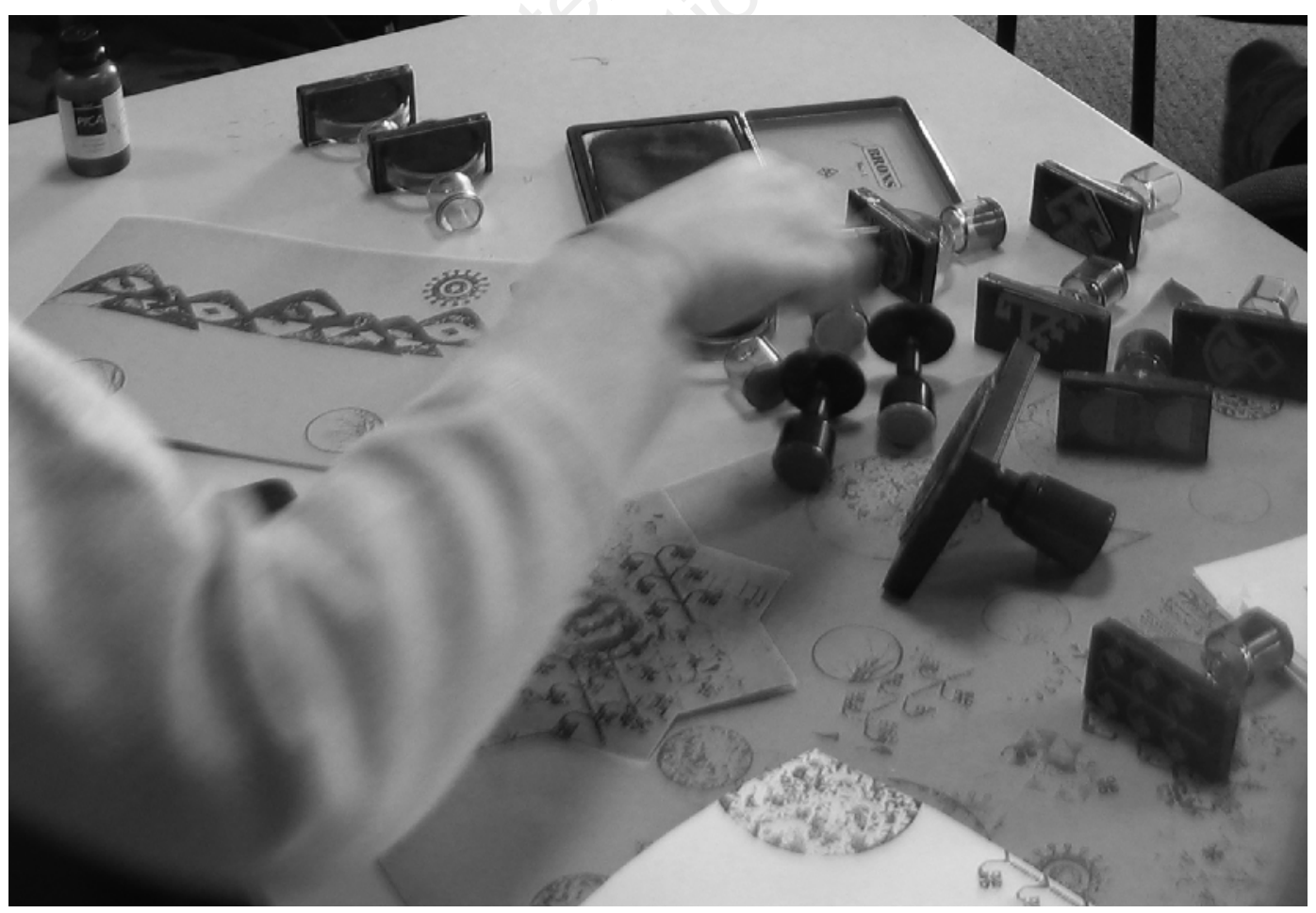


The second set of questions measured the students' knowledge of the carpet production process and investigated how the careful production and the meticulous craftsmanship involved gave the carpets deeper meaning. This opened a door to a behind-the-scenes view of the production cycle of the carpet business that consumers are not often privy to. This experience educated students on the complex production chain and numerous processes involved before finally arriving at a finished product. Because this is a femaledominated occupation, at this point we discussed women's roles in society, education and lifestyle. It was eye-opening to see changes in society reflected in the transformation of carpet production, the changing purpose of carpet making and the circumstances in which the carpets are made.

These questions gave students a chance to think about the carpet in relation to its creation and design process. Before they started their art-based inquiry, the students were given a task - brainstorming a synthesis of their own experiences with carpets - to help them employ carpet motifs to convey a particular meaning. Their first assignment was to cover a surface that would not normally be carpeted, to use the carpet symbols in an innovative way. This exercise triggered spatial and critical thinking that invited students to fuse the physical presence of the carpets with intangible ideas, infusing new meaning into the topic. These artistic exercises involved making connections between carpets and other objects. Students sketched spaces without carpets and explored carpets' presence on certain surfaces with a changing structure that foregrounded spatial concepts as noted by Grossner and Janelle (2014).

Once they had laid the groundwork, students contemplated their personal histories and explorations in relation to carpets to create an artwork that would tell something about the society that they live in today or hope to live in someday. At this stage of the project, students researched carpets on their own, looking at contemporary and historical sources. Some of the students also interviewed their parents, grandparents and shop owners. In the end, they made two proposals for an artistic piece in relation to the carpet. After a peer in-class critique of their proposals, and one-on-one discussions with the instructor, students focused on a single project that was a culmination of their proposed ideas and worked towards refining their project to make a finished piece supported by a written report. In the report, they reflected on their findings and explained the social and aesthetic issues that they chose to focus on, analysing the concepts that they associated with handmade carpets and how these notions had evolved during the process.

\section{STUDENT ARTWORKS ON THE CARPET}

This interdisciplinary art project facilitated a personal approach to learning. After extensive brainstorming, visual research and a brief literature review, each student focused on a single aspect of the carpets: their motifs, re-usage, purposes or production. Many of the selected works that were exhibited on campus and discussed in this article expressed a pensive attitude towards societal changes.

In Figure 6, MH focused on a single motif called Fetter (Bukağı in Turkish) that originated in the Kars region and is related to birth and reproduction. Printed on the shirt is a symbol for the'unity of man and woman, the continuity of the family, fertility and the lover's desire to unite' (Erbek 2002: 77). A symbolic belt around the middle represents the lover's devotion and is a sign of eternal unification and faithfulness in marriage. While this is an idealistic symbol used in carpets for centuries, it is at odds with the state of marriage in Turkey today as divorce rates are on the rise and women's rights are at times still being violated. 


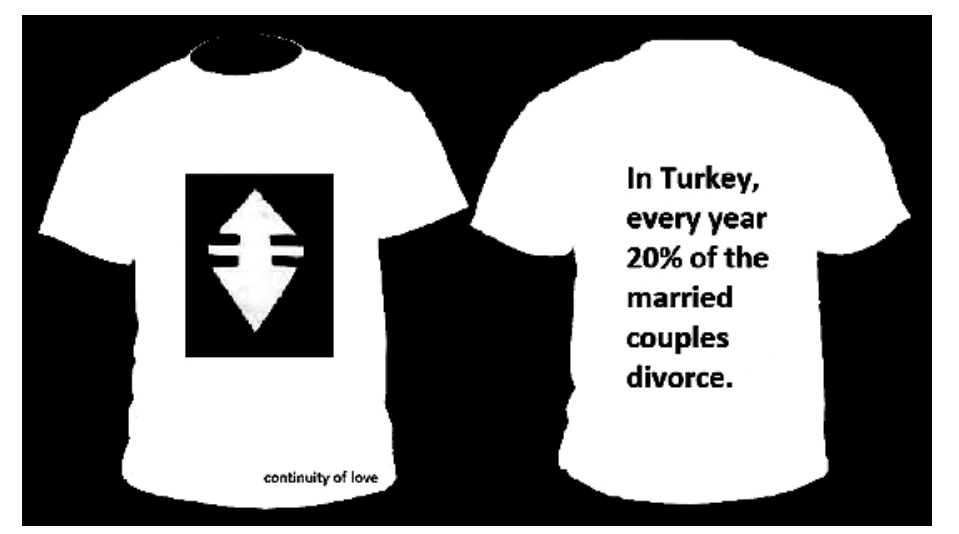

1.

2.

3.

4.

5.

6.

7.

8.

9.

10.

11.

12.

13.

14.

Figure 6: Student work, 'Culture is not crime but art' by MH.

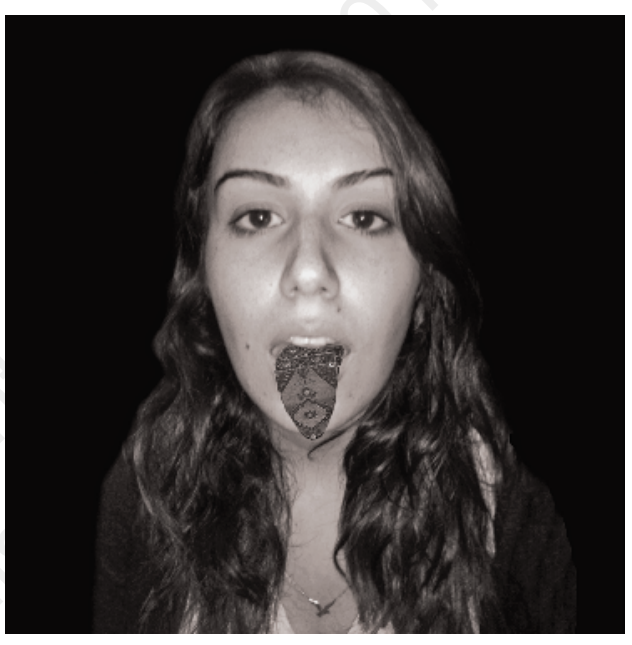

17.

18.

19.

20.

21.

22.

23.

24.

25.

26.

27.

28.

29.

30.

31.

32.

33.

Figure 7: Student work, 'Lack of communication' by ZŞ.

ZŞ's work (Figure 7) reflects on the role of the carpet weaver and the 38. position of women in society, hinting at gender issues at large. Considering 39. the collaged carpet, the work reveals a subtext, something hidden. This work 40. shocks the viewer out of preconceived notions as the photographed woman 41 . boldly stares back, unlike the more demur look expected from a carpet weaver, 42 . and unexpectedly sticks her tongue out in an expression of non-conformity. 43. Inspired by the visual narrative of the carpets that was explored in class, she 44 . contemplates the absence of women's voices expressed as an element of the 45 . carpets' visual as follows:

[...] the carpet-tongue represents all the things an individual wants to say. Her past, how she was raised, her values, her inner world is a carpet that came out of her mouth and actually all of these elements shape her carpet's appearance $[\ldots]$. 


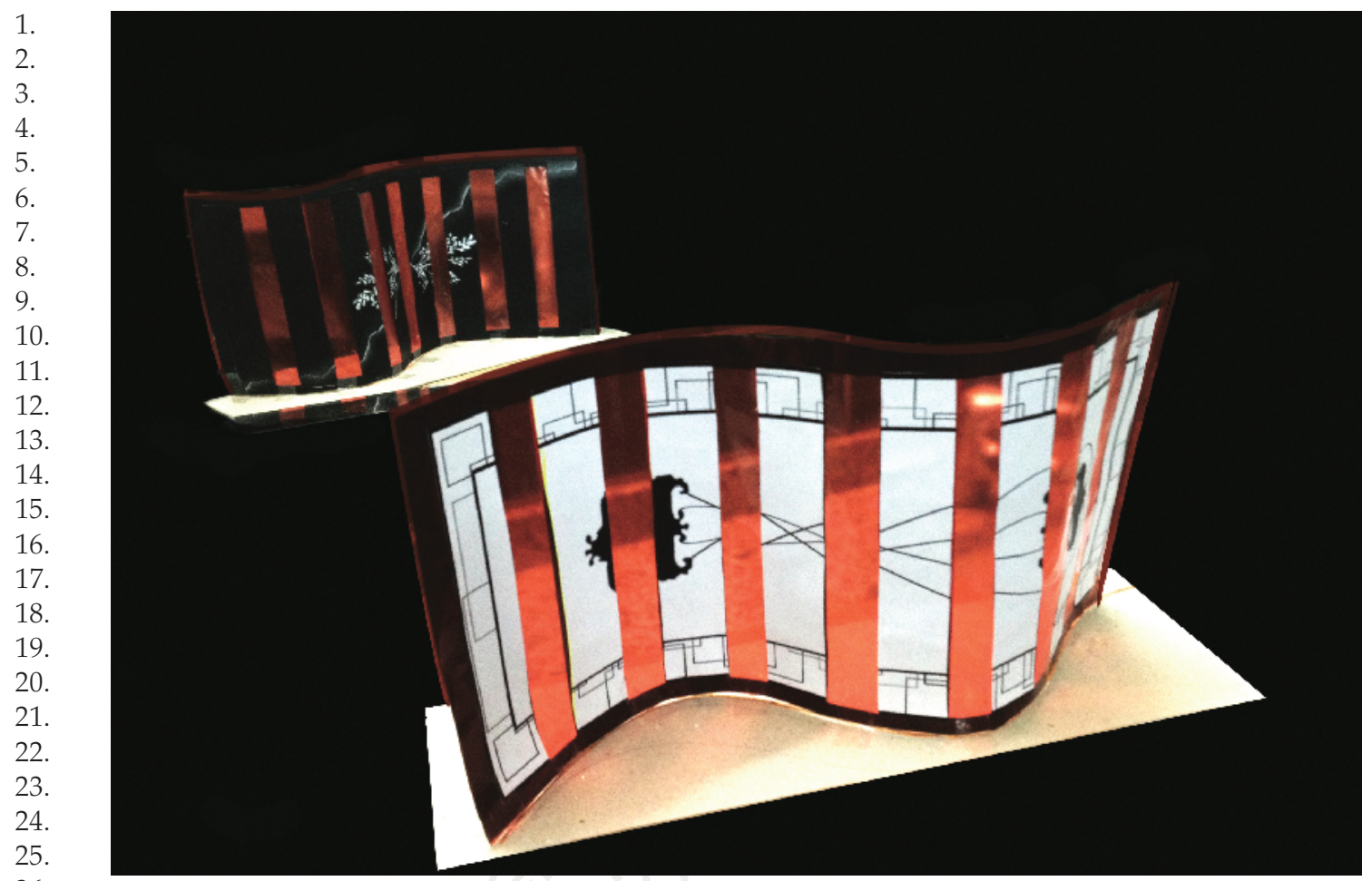

In Figure 8, İBÖ focused on dissecting the patterns of the carpet by separating the layers in Photoshop and then simplifying the motifs. This work viewed the carpet through a digital lens, questioning its flatness, unified surface and its stereotypical orientation. In the final stage, İBÖ generated a see-through image that shifted with light and movement. İÖ stated that her work was a synthesis of contemporary and traditional, offering a sensory experience because of its contrasting textured and non-textured surface.

\section{EVALUATION}

The project introduced numerous insights on how material culture such as handmade carpets could enable students to engage in art while reflecting on the contemporary state of society. Clarke (1998: 73) states, 'Material culture, its acquisition and appropriation, is integral to the construction and negotiation of social worlds and identities'. During the initial portion of the project, students shared memories and family stories pertaining to carpets in their own homes or other spaces, making apparent the significance of carpets in Turkey. The second portion of the project exposed the students to the history of the carpets and related art and design works, helping to create an allinclusive image of the carpet through different eras. The hands-on artistic exercises enabled students to creatively engage with the subject, experiment, play, pick and choose, thus enabling them to seek and introduce their own narratives. 
Finally, the students delivered an artwork that stemmed from their own life experiences, critical views and the knowledge acquired in class. By doing so, students not only gained insight into the importance of the material culture they are exposed to and spatial relationships they are involved with, but they also explored their own creative abilities to present an artistic statement on a selected subject. The project presented an opportunity to stop and observe the importance of material culture as a signifier of a transforming self and society. As stated by Jacobs and Malpas (2013: 286), 'To investigate our relation to objects is thus to investigate the very structure of self and identity'. This project was a catalyst that encouraged students to be in touch with their surroundings, material culture and society, and helped students communicate their personal views on tradition and change. The result saw undergraduates tackle a multidimensional problem that unfurled in the form of artwork that in turn surfaced relational aspects of their being.

\section{CONCLUSION}

This article presented a culturally responsive approach by introducing an interdisciplinary group of undergraduates to art, using carpets as a common denominator to convey to understanding and communication. The project encouraged undergraduates to deepen their relationship with their surroundings by way of studying carpets and producing an artwork. The results of the project were manifold as each student took the initiative to reflect on issues that were raised from a personal, cultural and a universal standpoint. Some works focused on the diminishing cultural heritage of carpets, some started societal discussions, while other works revealed personal bonds to the carpet culture.

When the early answers and final reports were compared, a shift in the opinions on carpets became apparent. In the beginning, most students perceived carpets as decorative textile objects, but by the end, most of the reports involved a certain level of critical thinking on the ideation process and had broadened the context to a societal perspective. While the Turkish national and cultural context of carpets was selected as a starting point for this project, the premise of the project if applied elsewhere could focus on any form of material culture as a means of questioning personal histories in relation to broader histories. In artistically re-evaluating the status of present-day carpets, students were also invited to reflect on their transforming selves by studying and manipulating something familiar to them at the same time as conceptualizing resolutions on changing societies at large. Some projects had messages that surpassed national boundaries and went so far as to utilize the carpets to convey universal messages.

In this project, students were encouraged to interpret shifting perceptions on the tradition of the carpet and evaluate changes in society. During this process, they not only improved their visual and cultural literacy but also learned to utilize art to express their emotions and ideas, while questioning their everyday surrounding and envisioning the future. Besides contemplating immediate surroundings, students used art as a method to evaluate material culture that yielded insight into local and global societies' transformation on multiple levels. Thus, at the end of the project, the students' creative output inspired by a material cultural form, carpets, synthesized their thoughts and feelings towards their social environment, uniting local with global in a hybrid and a dynamic way. 


\section{REFERENCES}

Aronson, B. and Laughter, J. (2016), 'The theory and practice of culturally relevant education: A synthesis of research across content areas', Review of Educational Research, 86:1, pp. 163-206.

At1l, E. (1980), Turkish Art, Washington, DC: Smithsonian Institution Press.

Bolin, P. E. and Blandy, D. (2003), 'Beyond visual culture: Seven statements of support for material culture studies in art education', Studies in Art Education, 44:3, pp. 246-63.

Clarke, A. J. (1998), 'Window shopping at home: Classifieds, catalogues and new consumer skills', in D. Miller (ed.), Material Cultures: Why Some Things Matter, London: UCL Press Limited.pp. 73-103.

Daftari, F., Bhabha, H. and Pamuk, O. (2006), Without Boundary: Seventeen Ways of Looking, New York: The Museum of Modern Art New York.

Dahl, R. (2000), 'The wish', in R. Dahl, Skin and Other Stories, New York: Puffin Books.

Denny, W. B. (2003), The Classical Tradition in Anatolian Carpets, Washington, DC: Textile Museum Press.

Dunnigan, J. (2013), 'Thingking', in R. Somerson and M. L. Hermano (eds), The Art of Critical Making, New Jersey: Wiley \& Sons, pp. 94-116.

Eisner, E. (2008), 'Art and knowledge', in J. Gary Knowles and Ardra L. Cole (eds), Handbook of the Arts in Qualitative Research, California: Sage Publications, pp. 3-13.

Erbek, M. (2002), From Çatalhöyük to the Present: Anatolian Motifs, Ankara: Republic of Turkey Ministry of Culture.

Giannachi, G., Kaye, N. and Shanks, M. (2012), Archaeologies of Presence, New York: Routledge.

Grossner, K. and Janelle, D. G. (2014), 'Concepts and principles for spatial literacy', in D. G. Janelle, K. Grossner and D. R. Montello (eds), Space in Mind: Concepts for Spatial Learning and Education, Massachusetts: The MIT Press.

Gürmen, A. (2008), Ninemin Kilimi, İstanbul: Kırlangıç Publications.

Hart, K. (2011), Modernliği Dokumak: Bir Batı Anadolu Köyünde Hayat Aşk Emek, İstanbul: Koç University Press.

Jacobs, K. and Gabriel, M. (2013), 'Introduction: Homes, objects and things', Housing, Theory and Society, 30:3, pp. 213-18.

Jacobs, K. and Malpas, J. (2013), 'Material objects, identity and the home: Towards a relational housing research agenda', Housing, Theory and Society, 30:3, pp. 281-92.

Kapucu, B. and Shafrir, T. (2012), Istanbul Design Biennale Program Booklet, İstanbul: İKSV Publications.

Kokko, S. and Dillon, P. (2016), 'Engaging trainee teachers with crafts and cultural heritage', International Journal of Education through Art, 12:1, pp. 21-37.

Lowenthal, D. (2000), 'Stewarding the past in a perplexing present', in E. Avrami, R. Mason and M. de la Torre (eds), Values and Heritage Conservation, Los Angeles: Getty Conservation Institute, pp. 18-25.

Mäkelä, M. and Löytönen, T. (2017), 'Rethinking materialities in higher education', Art, Design \& Communication in Higher Education, 16:2, pp. 241-58.

Masters, H. G. (2015), 'Nevin Aladağ scene from the street', ArtAsiaPacific, 93, May/June, pp. 92-101.

McNiff, S. (2008), 'Art and knowledge', in J. Gary Knowles and Ardra L. Cole (eds), Handbook of the Arts in Qualitative Research, California: Sage Publications, pp. 29-40. 
Miller, D. (2005), Materiality, Durham: Duke University Press.

Quataert, D. (1986), 'Machine breaking and the changing carpet industry of western Anatolia, 1860-1908', Journal of Social History, 19:3, pp. 473-89,

Sekimoto, S. (2012), 'A multimodal approach to identity: Theorizing the self through embodiment, spatiality, and temporality', Journal of International and Intercultural Communication, 5:3, pp. 226-43.

Spooner, B. (2011), 'Afghan wars, oriental carpets, and globalization', Expedition Magazine, 53:1, pp. 11-20.

Stokrocki, M. (2001), 'Children's ethno-aesthetic responses to a Turkish carpet: A cross-cultural study in three cultures', International Journal of Art and Design Education, 20:3, pp. 320-31.

Tilburg, M. van (2011), 'Rethinking the carpet paradigm: Critical footnotes to a theory of flatness, Yayoi Kusama, Mai-Thu Perret, Louise Bourgeois', in T. Weddigen (ed.), Meta-Textile: Identity and History of a Contemporary Art Medium, Textile Studies 2, Emsdetten and Berlin: Gebr. Mann Verlag, pp. $131-42$.

Türe, M. and Gere, G. (2016), 'Continuity through change: Navigating temporalities through heirloom rejuvenation', Journal of Consumer Research, 43:1, pp. $1-25$.

Ünal, Ş. (2005), Anatolian Kilims, vol. 1/2, Ankara: Semih Offset Publications.

van den Akker, J. (2014), 'Art-based learning: Painting the journey of selfrealisation', Reflective Practice, 15:6, pp. 751-65.

\section{SUGGESTED CITATION}

Aktaş, B., M. and Alaca, I., V. (2019), 'Exploring material culture of carpets in Turkey via an art project', Art, Design \& Communication in Higher Education, 18:1, pp. 17-33, doi: 10.1386/adch.18.1.17_1

\section{CONTRIBUTOR DETAILS}

Ilgım Veryeri Alaca is an assistant professor and a practicing artist at Koç University, Department of Media and Visual Arts. Prior to this, she taught at Bilkent University and University of Richmond. She has a Ph.D. from Hacettepe University, an MFA from University of Illinois at Urbana Champaign and an MA from California State University. Her articles have appeared in journals such as Leonardo, the Journal of Modern Craft, International Journal of Education Through Art, the Journal of Illustration, Drawing: Research, Theory, Practice and Interaction Design and Architecture(s) Journal (IxD\&A). She is the co-editor of the book entitled Artist in Residence Programs and Cultural Connections (Norgunk, 2012). She has presented in conferences such as College Art Association's Annual Conference (CAA), The European Conference on Educational Research and PostHaus: Foundations in Art: Theory and Education (FATE). She is represented at museums in Italy, Poland, Turkey and United States.

Contact: Koç University, Department of Media and Visual Arts, Rumelifeneri Yolu, Sariyer, 34450 Istanbul, Turkey.

E-mail: ialaca@ku.edu.tr 
1. Bilge Merve Aktaş holds a BSc in industrial product design from Istanbul 2. Technical University and an MA in Design Technology and Society programme 3. from Koç University. Currently, she is conducting her practice-led doctoral 4. research at Aalto University on craft and design interaction with case stud5. ies in felt making. Her research interests cover issues in craft, design, maker 6. culture and materiality.

7. Contact: Aalto University, School of Arts, Design and Architecture, 02150 8. Espoo, Finland.

9. $\quad$ E-mail: bilge.aktas@aalto.fi

11.

12.

ㅂ. https://orcid.org/0000-0001-6481-9021

13.

14.

15.

Ilgım Veryeri Alaca and Bilge Merve Aktaş have asserted their right under the Copyright, Designs and Patents Act, 1988, to be identified as the authors of this work in the format that was submitted to Intellect Ltd. 
